\title{
Incidence of Gliomas in Municipalities of Zenica - Doboj Canton in Bosnia and Herzegovina - A 10-Year Study
}

\author{
Bosna Hersek Zenica - Doboj Kantonu Yerel Bölgelerinde \\ Gliyoma İnsidansı - 10 YIllık Bir Çalışma
}

\author{
Nadija EKINOVIC $\odot$, Hakija BECULIC $\odot$, Rasim SKOMORAC $\bullet$, Aldin JUSIC $\bullet$, Anes MASOVIC $\bullet$, \\ Damir KURTAGIC $\odot$, Nedim BARUCIJA $\odot$
}

Ethics Committee Approval: This study was approved by the Ju Kantonalna Bolnica Zenica Ethics Committee, 27 December 2019, 00-3-02-12954-7/20.

Conflict of interest: The authors declare that they have no conflict of interest. Funding: None.

Informed Consent: Not Applicable.
Cite as: Ekinovic N, Beculic H, Skomorac R, et al. Incidence of gliomas in municipalities of zenica - doboj canton in Bosnia and Herzegovina - A 10-year study. Medeniyet Med J. 2020;35:136-41.

\begin{abstract}
Objective: To determine the incidence of gliomas in Zenica - Doboj Canton. Moreover, to analyse its potential connection to sociodemographic characteristics and its distribution throughout municipalities of Zenica - Doboj Canton in the period of 2009-2019.

Method: This retrospective, descriptive - analytical, 10 - year study included 146 patients from Zenica -Doboj Canton. Data were obtained and reviewed from patient's medical records. Patients' sociodemographic characteristics and pathohistological diagnosis were included in the study. Age, gender, and the place of birth were analysed and correlated with types and grades of glial tumors according to the World Health Organisation's latest classification.

Results: The study consisted of 146 patients including 84 (58\%) males and 62 (42\%) females. The most common pathohistological diagnosis was glioblastoma multiforme, a grade IV glioma in both females (26\%) and males (35\%), in total 91 (62\%) patients, and the rarest was oligoastrocytoma, in 2 (1\%) cases. The municipality of Kakanj had the highest incidence of glioma with 29 out of total of 146 cases (0.077\%) and the highest incidence in females (0.069\%) with 13 cases. The municipality of Vares had the highest incidence of glioma (0.114\%) with 5 out of 84 male cases, while in the cities of Breza and Olovo any cases with glioma were not detected The results showed statistically significant differences in incidences of gliomas according to the region of residence.

Conclusion: The analysis of data indicated that there are significant connections between the occurrence of gliomas and sociodemographic characteristics of patients from Zenica - Doboj Canton.
\end{abstract}

Keywords: Glioma, incidence, epidemiology

öz

Amac: Zenica - Doboj Kantonu'ndaki gliyoma insidansını belirlemektir. Dahası, 2009 ile 2019 yılları arasındaki gliyoma sıklığının sosyodemografik özellikler ve Zenica - Doboj Kantonu'ndaki yerel bölgelerdeki dağılımı ile ilişkilerini analiz etmektir.

Yöntem: Retrospektif, betimleyici - analitik, 10 yıllık çalışma Zenica - Doboj Kanton'undan 146 hastayı içermektedir. Araştırma verisi hastaların tıbbi kayıtlarından elde edilmiştir ve gözden geçirilmiștir. Hastaların sosyodemografik özellikleri ve patohistolojik tanıları araștırmaya dahil edilmiştir. Yaş, cinsiyet ve doğum yeri bilgileri analiz edilerek Dünya Sağlık Örgütü'nün en son sınıflandırmasına göre gliyal tümör türleri ve dereceleri ile korelasyonlarına bakılmıştır.

Bulgular: Araştırmaya 84 (\%58) erkek ve 62 (\%42) kadın, toplam 146 hasta katılmıştır. En yaygın patohistolojik tanı Glioblastoma multiforme, derece IV gliyoma kadınlarda (\%26) ve erkeklerde (\%35), toplamda 91 (\%62) hastada görülmüștür; en düș̈̈k görülen tanı ise 2 hastada (\%1) görülen oligoastrostiomadır. Kakanj toplam 146 vaka arasından 29 vaka ile en yüksek gliyoma insidansına $(\% 0,077)$ ve kadınlarda 13 vaka ile en yüksek insidansa $(\% 0,069)$ sahiptir. Vares toplam 84 erkek vaka arasından 5 erkek vaka ile erkeklerde en yüksek insidansa $(\% 0,114)$ sahiptir. Breza'da ve Olovo'da hiç vaka bulunmamaktadır. Bulgular ikamet bölgesine göre istatistiksel açıdan anlamlı düzeyde farklı gliyoma insidansları olduğunu göstermiştir.

Sonuç: Veri analizi göstermiştir ki Zenica - Doboj Kantonu'nda gliyomaların meydana gelişi ile hastaların sosyodemografik özellikleri arasında anlamlı bağlantılar bulunmaktadır.

Anahtar kelimeler: Gliyoma, insidans, epidemiyoloji
Received: 17 January 2020

Accepted: 30 April 2020

Online First: 30 June 2020

Corresponding Author:

N. Ekinovic

ORCID: 0000-0001-7588-3627

Cantonal Hospital Zenica,

Department of Neurosurgery,

Zenica, Bosnia and Herzegovina

nadijae@hotmail.com

H. Beculic

ORCID: 0000-0002-6904-2490

R. Skomorac

ORCID: 0000-0002-7085-5720

A. Jusic

ORCID: 0000-0001-7303-009X

A. Masovic

ORCID: 0000-0002-0789-4591

Cantonal Hospital Zenica,

Department of Neurosurgery,

Zenica, Bosnia and Herzegovina

D. Kurtagic

ORCID: 0000-0002-9729-5727

Cantonal Hospital Zenica,

Department of Anesthesiology and Intensive Care Unit,

Zenica, Bosnia and Herzegovina

N. Barucija

ORCID: 0000-0002-9363-3338

Cantonal Hospital Zenica,

Department of Otorhinolaryngology and Maxillofacial Surgery,

Zenica, Bosnia and Herzegovina 


\section{INTRODUCTION}

Glial tumors are among diverse set of tumors developing from the glial brain cells. Generally, tumors of the central nervous system are rare comparing to the other types of tumors affecting the human body ${ }^{1}$. The latest Globocan report for 2018 estimated a total age-standardized incidence rates (ASRs) of 3.5 per 100.000 and a mortality ASR of 2.8 per 100.000 people worldwide ${ }^{2}$. The most common gliomas are unfortunately the most malignant forms of brain cancer ${ }^{3}$. They tend to occur frequently in male population and when speaking of age, there is no specific age distribution ${ }^{4}$. Most of them present with headache, following nausea, progressive neurologic deficit in 68\%: usually motor weakness in $45 \%$, and seizures in $26 \%$ of the cases. Seizures are often focal type in onset (due to cortical irritation in the area of the tumor) ${ }^{5}$. They are specific to supratentorial position of tumors. A constant headache as a leading symptom may occur with or without elevated intracranial pressure (ICP). Focal neurologic deficit can be related to the function of the localized brain lesion or due to the cortical irritation or compression. This means that clinical presentation is not quite specific. That is the major reason why their brain lesions have already damaged the surrounding healthy tissue by the time patients receive any kind of diagnosis. Glial tumors are primary tumors and they rarely cause metastases in remote organs ${ }^{6}$.

It should be noted that any study related to the characteristics and the incidence of gliomas has not been published in Bosnia and Herzegovina yet. More perceptive analysis of differences in glioma incidence in different populated areas may give a better voice in raising awareness, which will consequently lead to developing more efficient diagnostics and treatment procedures. Furthermore, a more thorough research on the environmental risk factors may give us better readings of pathophysiological mechanisms in the development of the glioma itself. Eventually, these problems will have to be dealt with. So, the aim of this study is to determine incidence of glial tumors in Zenica-Doboj Canton, in Bosnia and Herzegovina and to analyse its distribution throughout cantonal municipalities in the period of 2009-2019.

\section{MATERIALS and METHODS}

A total of 146 patients born on the territory of Zenica-Doboj Canton, underwent surgical resection due to glial tumors between October 2009 and October 2019 in the Department of Neurosurgery at Cantonal Hospital Zenica, Bosnia and Herzegovina. This is a 10-year-retrospective, descriptive-analytical study with statistical processing. Microsoft Office Excel 2007 and 2013 with XLSTAT add-in was used for statistical analysis of the data.

Data were obtained and reviewed from the patients' medical records, included sociodemographic characteristics (gender, age, and the place of birth) and pathohistological diagnosis (PHD).

The study analysed the incidence of glial tumors by gender and age distribution, the place of birth, and pathohistological type, focussing on peculiarities possibly as a result of environmental pollution. The places of birth included all the municipalities - Breza, Doboj Jug, Kakanj, Maglaj, Olovo, Tešanj, Vareš, Visoko, Zavidovici, Zenica, Žepce, and Usora. Pathohistological analysis has been presented according to the WHO classification of gliomas as Grades I, II, III and IV which were furthermore classified as astrocytoma, oligodendroglioma, oligoastrocytoma, ependymoma, and glioblastoma multiforme (GBM) ${ }^{7}$.

Descriptive and comparative statistical ( $x^{2}$ test) methods were used. Results were presented in the tables and expressed as relative and mean values. The level of statistical significance was set to less than $5 \%$. 


\section{RESULTS}

A total number of 146 patients including 62 (42\%) females, and 84 (58\%) males underwent surgical resection of brain glioma in the period of October 2009-October 2019. The female to male crude ratio was $1: 1.33$. Mean age for male patients was 51.9 years (the youngest being 5 years old) and for females was 52.9 years (the youngest being 6 years old). There were 8 patients younger than 20 (5\%) and no one was older than 81 years of age (Table 1).

Table 1. Age and gender distribution of the patients.

\begin{tabular}{llll}
\hline & \multicolumn{3}{c}{ No (\%) of patients } \\
\cline { 2 - 4 } Age (years) & $\begin{array}{l}\text { Males (\% out } \\
\text { of males) }\end{array}$ & $\begin{array}{l}\text { Females (\% out } \\
\text { of females) }\end{array}$ & $\begin{array}{l}\text { Total (out of } \\
\text { total) }\end{array}$ \\
\hline $0-20$ & $4(5 \%)$ & $4(6 \%)$ & $8(5 \%)$ \\
$21-40$ & $16(19 \%)$ & $12(20 \%)$ & $28(19 \%)$ \\
$41-60$ & $41(48 \%)$ & $20(33 \%)$ & $61(42 \%)$ \\
$61-80$ & $25(29 \%)$ & $24(40 \%)$ & $49(34 \%)$ \\
$81+$ & 0 & 0 & 0 \\
Total & $86(58 \%)$ & $60(42 \%)$ & $146(100 \%)$ \\
\hline
\end{tabular}

The most frequent PHD was GBM, as Grade IV glioma in both males and females that occurred in 91 patients (62\%) in total. Astrocytoma was the second most common PHD that occurred in 44 $(30 \%)$ of the treated patients. Ependymoma was found in $6(4 \%)$ and oligodendroglioma in $3(2 \%)$ patients. The rarest PHD was oligoastrocytoma that occurred in 2 cases (1\% of total number of patients). According to the epidemiology of glial brain tumors in Europe, our incidence of PHD presented was not statistically significant ( $>>0.05)$. There was no statistically significant difference between our results and the expected incidence rates $\left(x^{2}=1.305\right)$ (Table 2$)$.

According to the 2016 World Health Organization Classification of Tumors of the Central Nervous System, pathohistological types are sorted into four grades as low-grade gliomas (Grades I and II) and high-grade gliomas (Grades III and IV). The higher the grade, the higher was the tendency of malignant proliferation ${ }^{8}$. Grade I gliomas were the rarest ones that were found in 8 cases $(6 \%)$, distributed evenly in $4(3 \%)$ males and $4(3 \%)$ females. Grade II gliomas occurred in 21 (14\%) cases, including $8(5 \%)$ male and in $13(9 \%)$ female patients. Grade III glioma was the second most common diagnosis in the group. It was found in $15(10 \%)$ males and $11(8 \%)$ females. In this evaluation, there were 91 (61\%) cases with Grade IV glioma (GBM) which makes GBM unfortunately the most common PHD. Grade IV gliomas were found in 55 males (35\%) and in 36 (26\%) females (Table 3).

Table 2. Distribution of pathohistological diagnosis.

\begin{tabular}{lll}
\hline PHD & $\begin{array}{l}\text { Patients } \\
\text { n (\%) }\end{array}$ & $\begin{array}{l}\text { Epidemiology of glial brain } \\
\text { tumors in Europe } \mathbf{2}^{2}(\%)\end{array}$ \\
\hline Astrocytoma & $44(30)$ & 27 \\
Oligodendroglioma & $3(2)$ & 5 \\
Oligoastrocytoma & $2(1)$ & 1 \\
Ependymoma & $6(4)$ & 4 \\
GBM & $91(62)$ & 63 \\
Total & $146(100)$ & 100 \\
\hline
\end{tabular}

Tests on contingency tables

$\mathrm{x}^{2}$ observed value $\mathrm{x}^{2}$ critical value P value DF Pearson's Phi $\begin{array}{lllll}1.305 & 9.488 & 0.860 & 4 & 0.081\end{array}$

PHD: Pathohistological Diagnosis

Table 3. Glioma grade according to WHO classification compared to gender distribution.

\begin{tabular}{lllll}
\hline Grade & I & II & III & IV \\
\hline Total & $8(6 \%)$ & $21(14 \%)$ & $26(18 \%)$ & $91(61 \%)$ \\
Male & $4(3 \%)$ & $8(5 \%)$ & $15(10 \%)$ & $55(35 \%)$ \\
Female & $4(3 \%)$ & $13(9 \%)$ & $11(8 \%)$ & $36(26 \%)$ \\
\hline
\end{tabular}

According to the latest census of population in Zenica-Doboj Canton (2013), Zenica remains the largest municipality with population of 110,663 people (54660 males and 56003 females). There were 35 cases with gliomas (19 males and 16 females) in Zenica with an average overall incidence of $0.032 \%(0.035 \%$ in males and $0.029 \%$ in females). The highest incidence of glioma was detected in the municipality of Kakanj with 29 cases (16 males and 13 females) among a population of 
37441 people (18651 males and 18790 females) (average overall incidence: $0.077 \%(0.086 \%$ in males and $0.069 \%$ in females). The highest incidence in males was in the municipality of Vareš with an average overall incidence of $0.114 \%$. There were 5 male cases in the population of 4373 males, and the highest incidence in females $(0.069 \%)$. was seen in the municipality of Kakanj. There were 13 cases out of female population of 18790. The lowest incidences were in the cities of Breza and Olovo since there were no cases of glial tumors in the last 10 years 9 . The analysis of occurrence in relation to the region of residence showed statistically significant difference in the incidence of gliomas in relation to the region of residence $(p<0.05)$. According to our test of independence there was a connection between the incidence of gliomas in relation to the municipalities $\left(x^{2}=27.933\right)$. The strongest correlation was observed between residents of Kakanj and incidence of glioma. Incidence of gliomas was slightly more common in males than in females. The test of independence showed that incidence of gliomas in men in regards to the total number of men in specific region is statistically significant $(p<0.05)$, while there is no statistical significance between incidence of gliomas in women in re-

Table 4. Incidence distribution in all municipalities in Zenica - Doboj Canton.

\begin{tabular}{llll}
\hline Municipality & Incidence (\%) & Males & Females \\
\hline Zenica & $0.032 \%$ & $0.035 \%$ & $0.029 \%$ \\
Žepce & $0.040 \%$ & $0.033 \%$ & $0.047 \%$ \\
Kakanj & $0.077 \%$ & $0.086 \%$ & $0.069 \%$ \\
Tešanj & $0.049 \%$ & $0.061 \%$ & $0.037 \%$ \\
Zavidovici & $0.036 \%$ & $0.039 \%$ & $0.033 \%$ \\
Maglaj & $0.043 \%$ & $0.061 \%$ & $0.026 \%$ \\
Visoko & $0.043 \%$ & $0.046 \%$ & $0.040 \%$ \\
Vareš & $0.067 \%$ & $0.114 \%$ & $0.040 \%$ \\
Doboj-Jug & $0.024 \%$ & $0.048 \%$ & $0.022 \%$ \\
Usora & $0.030 \%$ & $0.061 \%$ & $0.000 \%$ \\
Breza & $0.000 \%$ & $0.000 \%$ & $0.000 \%$ \\
Olovo & $0.000 \%$ & $0.000 \%$ & $0.000 \%$ \\
Total (No) & $0.038 \%$ & $0.044 \%$ & $0.032 \%$ \\
Tests on contingency tables & & & \\
P value & 0.003 & 0.042 & 0.189 \\
$x^{2}$ observed value & 27.933 & 20.216 & 14.861 \\
$x^{2}$ critical value & 19.675 & 19.675 & 19.675 \\
DF & 11 & 11 & 11 \\
Pearson's Phi & 0.009 & 0.011 & 0.009 \\
\hline
\end{tabular}

gards to the total number of women in a specific region (Table 4 ).

There was no statistically significant difference in terms of the grade of glioma and the region of residence (geographical position) of population in Zenica-Doboj Canton ( $p>0.05)$.

\section{DISCUSSION}

Analysis of our data indicated that gliomas are the most common in the fifth and sixth decade of life. That doesn't exclude the fact that this type of brain tumor can occur in all age groups, but low grade gliomas are most frequently seen in children and young adults are which means that treatment in these individuals has higher success and consequently higher survival rates. Previously published studies indicate the same distribution in incidence of glial tumors in all age groups ${ }^{10}$. Gender distribution confirmed that males are in higher risk of developing glial tumor than females. Despite the fact that males had much higher possibility of developing glial tumor in the past. Today, due to the modern life, females are closing in and therefore reducing the difference in incidence rate between males. Other reports suggest that male to female ratio was similar ${ }^{11}$. Gigineishvili et al. ${ }^{12}$ reported higher incidence of malignant tumors in males than in females, but according to their statistical analysis, there was no statistically significant difference in the incidence of glial tumors between age groups.

Globocan ${ }^{2}$ in 2018 reported their statistical analysis of the incidence of brain tumors worldwide. Compared to their results, data from this study indicates a much higher incidence. Also, Globocan's report suggests that the results of this study are much similar to the data from developing countries. The data regarding the low incidence of glial tumors, especially in the age group 0-20 years is consistent with the reports from other economically developing countries ${ }^{13}$. 
According to the WHO classification ${ }^{8}$, all tumors of the central nervous system are sorted out into 7 categories as tumors of neuroepithelial tissue, cranial and paraspinal nerves, meninges, lymphomas and hematopoietic neoplasms, germ cell tumors, tumors of the sellar region, and metastatic tumors ${ }^{8}$. Neuroepithelial neoplasms are always primary tumors and can be further classified into more subcategories as astrocytic tumors (pilocytic astrocytoma, diffuse infiltrating astrocytoma and anaplastic astrocytoma), oligodendroglial and mixed glioma tumors (Grade II or Grade III glioma) and ependymal type gliomas ${ }^{14}$. The most malignant form of all these gliomas is called glioblastoma multiforme $(G B M)^{15}$. It can arise de novo or as malignant proliferation from some other type of lower grade glioma. It is categorised as Grade IV glioma with highly progressive and rapidly enlarging tumor without very promising prognosis ${ }^{10}$. In this study, data showed significant dominance of high-grade gliomas. Astrocytoma and glioblastoma multiforme are the most frequent pathohistological diagnosis. Therefore, similar to the results of other studies we also found the highest incidence of gliomas among high grade tumors. Ostrom et al. ${ }^{11}$ reported that the gliomas represent $81 \%$ of primary brain tumors and amongst them, glioblastoma multiforme is one the most common pathohistological type of glioma. They showed that incidence of glioblastoma multiforme amongst other types of glial tumors was about $45 \%$ which was lower when compared with the results of this study (62\%). This discrepancy could be related to lack of modern diagnostic facilities and easily accessible healthcare delivery system ${ }^{11,13}$. Das et al. ${ }^{16}$ suggested that the second most common type of glioma is astrocytoma occurring in $25 \%$ the cases. Data from this study reported the incidence of astrocytoma as 30\%, apart from Grade IV astrocytoma (glioblastoma multiforme). Previous reports showed that many developing countries are lagging behind in reporting epidemiological data for brain tumors. According to WHO4, 149 countries were registered as developing countries. Despite the lack of data, the results indicate that there is very little difference between incidence rates of glial tumors. Hao et al. ${ }^{17}$ suggested that between many causes of gliomas cases being unidentifiable, differences in incidence involving different populated areas may lead us to the existence of potential environmental risk factors ${ }^{18}$. This study showed almost the same results. Our results showed unavoidable difference between municipalities as for incidence rates of gliomas. Some of our results showed incredibly high incidence of gliomas in municipalities such as Kakanj and Vareš, but without any occurrence of gliomas in municipaliites of Breza and Olovo. Regions with higher incidence are mostly industrial regions, so there could be some connection involved in higher occurrence of gliomas. Size of the population should not be a contributing factor as our results showed. Although, Breza and Olovo are regions with smaller population, the fact of having no occurrence of gliomas could be related to its geographical position, especially Olovo. Since it was confirmed that no other potential case of gliomas from Breza or Olovo were sent away, therefore some suspected epidemiological factors could be involved in raising potentially higher risk of developing a glial tumor. Furthermore, some regions with higher incidence rates amongst the others could be associated with potential risk factors such as exposure to ionizing radiation. Working with solvents, pesticides, and being exposed to nonionizing radiation such as cellular phones gave inconclusive results ${ }^{11}$. However, the question still remains unanswered. Potential factor contributing to the difference in incidence rates should be further examined in future studies.

\section{CONCLUSION}

In conclusion, results of the study have indicated that the incidence of glial tumors in Zenica-Doboj Canton is not much different than the incidence in other developing countries, but it is significantly higher than the incidence in developed countries. Furthermore, there is a significant correla- 
tion between the incidence rates of gliomas and sociodemographic characteristics of patients from Zenica-Doboj Canton.

\section{REFERENCES}

1. Adamson DC, Rasheed BA, McLendon RE, Bigner DD. Central nervous system. Cancer Biomark. 2010;9(1-6):193-210. [CrossRef]

2. World Health Organization. International Association of Cancer Registries. [Online]. [cited 2019 September. Available from: http://gco.iarc.fr/today/fact-sheets-cancers.

3. Mesfin FB, Al-Dhahir MA. Cancer, Brain Gliomas. In. Treasure Island: StatPearls Publishing LLC; 2019.

4. Khan I, Bangash M, Baeesa S, et al. Epidemiological trends of histopathologically WHO classified CNS tumors in developing countries: systematic review. Asian Pac J Cancer Prev. 2015;16(1):205-16. [CrossRef]

5. Mark S. Green berg M. Handbook of Neurosurgery. 8th ed. Thieme Medical Publishers I, editor. Tampa: Thieme Medical Publishers, Inc.; 2016.

6. Lian H, Daniels C, Han YP, et al. Incidence of metastatic disease and survival among patients with newly diagnosed primary CNS tumors in the United States from 2004-2013. J Cancer. 2019;10(13):3037-45. [CrossRef]

7. Beculic $H$, al. e. Hirurgija tumora centralnog nervnog sistema. $1^{\text {st }}$ ed. Tešanj: AGFA print; 2016.

8. Louis DN, Perry A, Reifenberger G, et al. The 2016 World Health Organization Classification of Tumors of the Central Nervous System: a summary. Acta Neuropathol. 2016;131(6):803-20. [CrossRef]

9. Herzegovina AfSoBa. Federalni zavod za statistiku Federacije Bosne i Hercegovine. [Online].; 2016 [cited 2019
November. Available from: http://fzs.ba/index.php/ popis-stanovnistva/popis-stanovnistva-2013/konacnirezultati-popisa-2013/.

10. Crocetti E, Trama A, Stiller C, et al. Epidemiology of glial and non-glial brain tumours in Europe. Eur J Cancer. 2012;48(10):1532-42. [CrossRef]

11. Ostrom QT, Bauchet L, Davis FG, et al. The epidemiology of glioma in adults: a "state of the science" review. Neuro Oncol. 2014;16(7):896-913. [CrossRef]

12. Gigineishvili D, Gigineishvili T, Tsiskaridze A, Shakarishvili $R$. Incidence rates of the primary brain tumours in Georgia--a population-based study. BMC Neurol. 2014;14:29. Published 2014 Feb 14. [CrossRef]

13. Katchy KC, Alexander S, Al-Nashmi NM, Al-Ramadan A. Epidemiology of primary brain tumors in childhood and adolescence in Kuwait. Springerplus. 2013;2(1):58. [CrossRef]

14. Villano JL, Parker CK, Dolecek TA. Descriptive epidemiology of ependymal tumours in the United States. Br J Cancer. 2013;108(11):2367-71. [CrossRef]

15. Alinezhad A, Jafari F. Novel management of glioma by molecular therapies, a review article. Eur J Transl Myol. 2019;29(3):8209. Published 2019 Aug 21. [CrossRef]

16. Das A, Tan WL, Teo J, Smith DR. Glioblastoma multiforme in an Asian population: evidence for a distinct genetic pathway. J Neurooncol. 2002;60(2):117-25. [CrossRef]

17. Xu H, Chen J, Xu H, Qin Z. Geographic Variations in the Incidence of Glioblastoma and Prognostic Factors Predictive of Overall Survival in US Adults from 2004-2013. Front Aging Neurosci. 2017;9:352. Published 2017 Nov 7. [CrossRef]

18. Persaud-Sharma D, Burns J, Trangle J, et al. Demographic Variation in the Frequency of Gliomas in Florida. Medicina (Kaunas). 2019;55(1):5. Published 2019 Jan 4. [CrossRef] 